\title{
Radiojód kontrasztanyagok által okozott vesekárosodás és megelőzése az újabb irodalmi adatok tükrében
}

\author{
Változtassunk a gyakorlaton! \\ Haris Ágnes dr. ${ }^{1}$ - Mátyus János dr. ${ }^{2}$ \\ ${ }^{1}$ Péterfy Kórház-Rendelőintézet és Manninger Jenő Országos Traumatológiai Intézet, \\ I. Belgyógyászat, Nephrologia és Gasztroenterológia Osztály, Budapest \\ ${ }^{2}$ Debreceni Egyetem, Általános Orvostudományi Kar, Klinikai Központ, Belgyógyászati Intézet, Nephrológiai \\ Tanszék, Debrecen
}

\begin{abstract}
A jelenlegi hazai gyakorlatban sokszor indokolatlanul korlátozzák a vesebetegek kontrasztanyagos vizsgálatát, és halasztódik a metformint szedők vizsgálata is, kontrasztanyag által okozott akut vesekárosodástól (contrast-induced acute kidney injury, CI-AKI) tartva. Összefoglalónk célja az ezzel kapcsolatos újabb ismeretek áttekintése és egy szakmai javaslat ismertetése annak érdekében, hogy a betegellátás szempontjából fontos vizsgálatok ne maradjanak el, ugyanakkor azok a maximális betegbiztonság jegyében készüljenek. Az elmúlt évek tanulmányai alapján a CI-AKI előfordulása a korábbinál kevésbé gyakori, és jelentősen különböző a kontrasztanyag intravénás vagy intraarteriális alkalmazásától függően. Legfontosabb rizikótényezője a csökkent glomerulusfiltrációs ráta (GFR), mely stabil állapotú vesebetegnél, intravénás kontrasztanyag adásakor $30 \mathrm{ml} / \mathrm{min} / 1,73 \mathrm{~m}^{2}$ alatt, intraarteriális alkalmazásakor $45 \mathrm{ml} / \mathrm{min} / 1,73 \mathrm{~m}^{2}$ alatt képez magas rizikót. Proteinuria esetén a CI-AKI és a kontrasztanyaggal társult akut vesekárosodás (contrast-associated kidney injury, CA-AKI) kockázata is nagyobb, ezért a számított GFR mellett indokolt a vizelet albumin/kreatinin vagy fehérje/kreatinin hányados meghatározása is a vizsgálat előtt. Az instabil állapot, az akut veseelégtelenség mindenkor magas kockázatot jelent, ilyenkor a számított GFR pontatlan, nem használható. Csökkent vesefunkció mellett figyelni kell a beadott kontrasztanyag mennyiségére, a vizsgálat 48-72 órán belüli ismétlésének kerülésére, a nemszteroid gyulladásgátlók vagy más nephrotoxicus szerek lehetőség szerinti szüneteltetésére. Prevenciós intézkedés a magas rizikóval bíró betegek esetében javasolt intravénás hidrálás formájában, fiziológiás koncentrációjú nátrium-klorid vagy nátrium-bikarbonát infúziójával. Az egyéb eljárások hatástalanok, és nem indokolt a beavatkozás utáni dialízis végzése sem végstádiumú veseelégtelen betegekben. A metformint $60 \mathrm{ml} / \mathrm{min} / 1,73 \mathrm{~m}^{2}$ feletti eGFR-rel rendelkezó beteg vizsgálata kapcsán szükségtelen elhagyni, ettől rosszabb vesemúködés esetén kell szüneteltetni. Amennyiben a vizsgálat indikációja sürgôsségi, az a metformin egyidejü elhagyásával elvégezhető, de a gyógyszer csak 48 óra múlva, az akut vesekárosodás kizárását követően adható vissza. Orv Hetil. 2022; 163(3): 83-91.
\end{abstract}

Kulcsszavak: radiojód kontrasztanyag, kontrasztanyag-indukált vesekárosodás, kontrasztanyaggal társult vesekárosodás, prevenció, metformin

\section{Occurrence and prevention of iodinated contrast agent-induced kidney injury in light of the newest literature data}

\section{Time to change our clinical practice!}

In the current clinical practice, studies with iodinated contrast agents are often limited in patients with kidney disease and delayed in those on metformin therapy due to fear of contrast-induced acute kidney injury (CI-AKI). We aim to review the most recent information about CI-AKI and provide recommendations in order to avoid cancellation of important contrast-enhanced tests, but maximize safety considerations. According to the most recent findings, CI-AKI occurs less frequently nowadays than previously, and depends significantly on the route of contrast administration (intraarterial or intravenous). The most important risk factor is the decreased GFR, which, in stable patients with intravenous contrast administration provides high risk if the eGFR is less than $30 \mathrm{ml} / \mathrm{min} / 1.73 \mathrm{~m}^{2}$, and with 
intraarterial contrast is less than $45 \mathrm{ml} / \mathrm{min} / 1.73 \mathrm{~m}^{2}$. In patients with proteinuria, the risk of both CI-AKI and CA-AKI (contrast-associated kidney injury) is increased, therefore urinary albumin/creatinine or protein/creatinine ratios are recommended to measure before the contrast material administration, beside the eGFR determination. Unstable condition, acute renal failure always mean high risk; in these cases, eGFR calculation is imprecise and useless. If renal function is decreased, the amount of contrast material needs consideration, repeated contrast-enhanced studies should be avoided in 48-72 hours, the non-steroidal anti-inflammatory agents and other nephrotoxic drugs have to be discontinued. For high risk patients, preventive intravenous hydration should be given, either by physiologic saline or sodium bicarbonate infusion. Other drugs aiming prevention have proved to be useless; dialysis treatment immediately after contrast administration in end-stage renal disease patients is unnecessary. There is no indication to discontinue metformin if eGFR is higher than $60 \mathrm{ml} / \mathrm{min} / 1.73 \mathrm{~m}^{2}$, but if the patient has less than that value, the metformin needs to be stopped. In urgent studies with contrast agent, metformin administration has to be discontinued simultaneously with the intervention, and this drug can only be readministered after ruling out acute kidney injury in 48 hours following contrast exposure.

Keywords: iodinated contrast agent, contrast-induced kidney injury, contrast-associated kidney injury, prevention, metformin

Haris Á, Mátyus J. [Occurrence and prevention of iodinated contrast agent-induced kidney injury in light of the newest literature data. Time to change our clinical practice!]. Orv Hetil. 2022; 163(3): 83-91.

(Beérkezett: 2021. július 27.; elfogadva: 2021. augusztus 27.)

\begin{abstract}
Rövidítések
ACE $=$ (angiotensin-converting enzyme) angiotenzinkonvertáló enzim; ACR = (American College of Radiology) Amerikai Radiológusok Kollégiuma; $\mathrm{ARB}=$ angiotenzinreceptor-blokkoló; $\mathrm{CA}-\mathrm{AKI}=$ (contrast-associated acute kidney injury) kontrasztanyaggal társult akut vesekárosodás; $\mathrm{CI}-\mathrm{AKI}=($ contrast-induced acute kidney injury) kontrasztanyag-indukált akut vesekárosodás; $\mathrm{CKD}=$ (chronic kidney disease) krónikus vesebetegség; eGFR = (estimated glomerular filtration rate) becsült glomerulusfiltrációs ráta; ESUR $=($ European Society of Urogenital Radiology) Európai Urogenitalis Radiológiai Társaság; $\mathrm{FDA}=($ U.S. Food and Drug Administration $)$ az USA Élelmiszer-biztonsági és Gyógyszerészeti Hivatala; $\mathrm{MR}=$ mágneses rezonancia; $\mathrm{NKF}=$ (National Kidney Foundation) Nemzeti Vese Alapítvány (USA); PC-AKI = (post-contrast acute kidney injury) posztkontraszt akut vesekárosodás; $\mathrm{PCI}=$ (percutaneous coronary intervention) percutan szívkoszorúér-beavatkozás; STEMI = ST-elevációval járó myocardialis infarktus; TAVI $=$ (transcatheter aortic valve implantation $)$ transzkatéteres aortabillentyü-implantáció; uACR = (urine albumin $/ \mathrm{kreati}$ nin ratio) vizelet albumin/kreatinin hányados; $\mathrm{uPCR}=$ (urine protein/creatinine ratio) vizelet fehérje/kreatinin hányados
\end{abstract}

\section{Miért kell napjainkban módosítani a kontrasztanyag által okozott akut vesekárosodás korábbi prevenciós irányelvét?}

A radiojód kontrasztanyag alkalmazásakor fellépő kontrasztnephropathiát, újabb elnevezése szerint kontrasztanyag által okozott akut vesekárosodást (contrast-induced acute kidney injury, CI-AKI) első alkalommal 1954-ben írták le [1]. A képalkotó vizsgálatok számának exponenciális növekedésével, különösen az instabil állapotú betegekben végzett coronariaintervenciós beavat- kozások kapcsán a kontrasztanyag alkalmazását követő vesekárosodás incidenciája is jelentősen megnövekedett. Jelentôsége, hogy az akut vesefunkció-romlás növeli mind a betegek alapbetegség miatti mortalitását, mind a szövődmény miatti hospitalizációs igényt, és romlik a krónikus vesebetegség $(\mathrm{CKD})$ hosszú távú progressziója is [2-4]. A CI-AKI epidemiológiája és prevenciójának lehetőségei a 2000-es években világszerte nagy hangsúlyt kaptak. A szakmai irányelvek jelentősen korlátozták a beszúküult vesefunkcióval élő betegek kontrasztanyagos vizsgálatát, és gyakran halasztódott a metformint szedők vizsgálata is. Az elmúlt években azonban számos tanulmány alapján a korábbinál lényegesen kevésbé gyakorinak látszik a CI-AKI előfordulása [4-6]. Az is egyértelmúvé vált, hogy jelentős a különbség a szövődmény kialakulásának gyakoriságában intravénásan vagy intraarteriálisan végzett kontrasztanyagos vizsgálat kapcsán $[7,8]$. A vesekárosodás diagnózisának felállításakor fontos annak differenciálása, hogy az adott betegben fellépő szövődmények valójában a kontrasztanyag alkalmazásának vagy magának az alapbetegségnek a következményei $[6,9]$.

Az optimális betegellátás szempontjából alapvetô jelentőségú, hogy az alkalmazott vizsgálat, beavatkozás szövődménymentes legyen, ugyanakkor a betegtól ne tagadjanak meg olyan ellátást, mely állapota javulásához vezethetne azért, mert túlzott, esetleg indokolatlan aggodalom kíséri a kontrasztanyag okozta vesekárosodás kialakulásának rizikóját. Jelen összefoglalónk célja a CI-AKI gyakoriságának, patomechanizmusának, rizikótényezőinek és a prevenció lehetőségeinek áttekintése és egy felújított hazai szakmai javaslat ismertetése (1. ábra) annak érdekében, hogy a kontrasztanyaggal végzett vizsgálatok a maximális betegbiztonság jegyében készülje- 


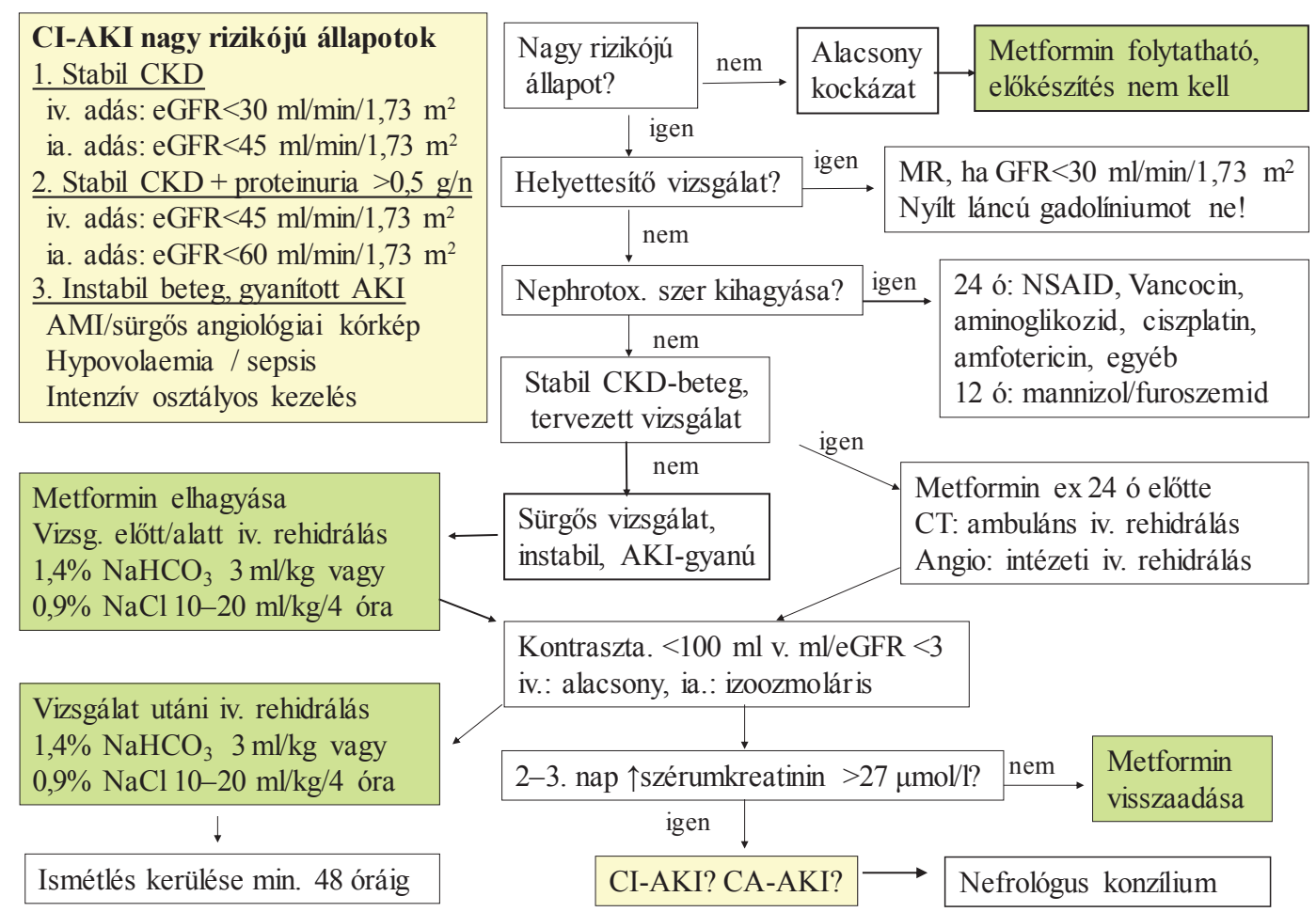

1. ábra $\quad$ Javasolt algoritmus a kontrasztanyagok vesekárosító hatásának megelőzésére

AKI = akut vesekárosodás; $\mathrm{AMI}=$ akut myocardialis infarktus; $\mathrm{CA}-\mathrm{AKI}=$ kontrasztanyaggal társult akut vesekárosodás; CI-AKI = kontrasztanyag-indukált akut vesekárosodás; $\mathrm{CKD}=$ krónikus vesekárosodás; $\mathrm{CT}=$ komputertomográfia; $\mathrm{eGFR}=$ becsült GFR; GFR = glomerulusfiltrációs ráta; $\mathrm{MR}=$ mágneses rezonancia; NSAID = nemszteroid gyulladáscsökkentő gyógyszer

nek, ugyanakkor ne fordulhasson elö, hogy a betegellátás szempontjából fontos beavatkozás elmaradjon vagy késlekedjen a vizsgálat vélt rizikója miatt [10].

\section{A kontrasztanyag által okozott akut vesekárosodás diagnosztikus kritériumai}

Az American College of Radiology (ACR) és a National Kidney Foundation (NKF), továbbá a European Society of Urogenital Radiology (ESUR) szakértői által készített szakvélemény alapján CI-AKI-nak a kontrasztanyag alkalmazását követóen 48-72 órával kialakult azon vesefunkció-romlás nevezhető, melynek hátterében egyéb etiológiai tényező kizárható [11, 12]. A jódos kontrasztanyaggal végzett vizsgálatot követő akut vesefunkcióromlás azon esete, amelynél a kontrasztanyag és a vesekárosodás között nem igazolható oki kapcsolat, a kontrasztanyaggal társult akut vesekárosodás (contrastassociated kidney injury, CA-AKI) vagy ennek szinonimájaként a posztkontraszt akut vesekárosodás (PC-AKI) elnevezést kapta [8, 11-13]. A CI-AKI prognózisának alaposabb megismerése következtében annak diagnosztikus kritériuma is változott: míg a 2000-es évek elején $0,5 \mathrm{mg} / \mathrm{dl}$, azaz $44 \mu \mathrm{mol} / 1$ szérumkreatinin-emelkedés vagy az alap kiindulási szérumkreatinin 25\%-os emelkedése volt a szövődmény bekövetkeztének laboratóriumi határértéke, ez az utóbbi években 0,3 mg/dl-re, azaz 27 $\mu$ mol/l szérumkreatinin-értékre vagy az alap-kreatinin- érték 50\%-os növekedésére módosult a kontrasztanyag alkalmazását követő 48-72 órában [2, 12, 14]. Fontos, hogy a CI-AKI kialakulása röviddel a kontrasztanyag alkalmazása után kerüljön megállapításra, mivel a vesefunkció az alapbetegség okozta instabilitás miatt is romolhat, így a későbbi, 4-7. nap közötti vagy azt követő kreatininemelkedés nagy valószínúséggel már etiológiailag eltérő mechanizmusú, ezt nevezzük CA-AKI-nak [15].

\section{A kontrasztanyag vesekárosodást előidéző hatásának patomechanizmusa}

A vese különösen érzékeny az oxigénhiányos állapotokra. Ennek magyarázata a szerv jelentős vérellátási igénye, mely normálkörülmények között a cardialis kiáramlás 25\%-a. A medulla keringése fiziológiás körülmények között is lényegesen kisebb, mint a kéregállományé, ezért hypoxiás állapotokban a medulla károsodása könnyen bekövetkezik. A radiojódos kontrasztanyag kettős mechanizmussal okoz vesekárosodást: a szer citotoxikus az endothel- és tubulussejtekre. A károsodó sejtekból felszabaduló szabad gyökök gátolják a nitrogén-oxid vasodilatator hatását, ennek elhúzódó vasoconstrictio lesz a következménye. A vasoconstrictio GFR-csökkenést és medullaris hypoperfusiót okoz, melyek következménye további tubulussejt-károsodás. A vesekárosodás másik tényezője a környezetéhez képest magas ozmolalitású 
kontrasztanyag, mely szintén a vesekeringés károsodását, következményes tubulussejt-károsodást, akut tubularis nekrózist idéz elő $[2,14]$.

\section{A kontrasztanyag által okozott akut vesekárosodás előfordulásának gyakorisága a kontrasztanyag intravénás alkalmazásakor}

Az elmúlt 2 évtizedben elvégzett nagyszámú klinikai tanulmány eredményei azt mutatták, hogy a kontrasztanyag által okozott vesekárosodás jelentősen eltéró gyakoriságú az akut megbetegedés miatti artériás kontrasztanyagos - elsősorban coronariaintervenció - és a vénás kontrasztanyagos CT-vizsgálatok után [8]. A korai évek publikációiban megjelent adatokkal szemben kiemelendően fontos, hogy intravénás kontrasztanyag alkalmazásakor még CKD esetén is alacsony a CI-AKI gyakorisága $[1,6,11,16]$ (1. táblázat).

Bár randomizált kontrollált vizsgálati eredmények nem állnak rendelkezésre a CT-vizsgálat kapcsán, azaz az intravénásan alkalmazott kontrasztanyag okozta vesekárosodás incidenciájának pontos meghatározására, obszervációs eredmények nagy számban kerültek publikálásra. Egy 21000 beteget magában foglaló amerikai megfigyeléses vizsgálatban nem találtak gyakoribb vesefunkció-károsodást az intravénás kontrasztanyagot kapó betegekben a natívan elkészített CT-vizsgálaton átesettekhez képest $(4,8 \%$, illetve $5,1 \%)$, bár az akut, illetve a krónikus vesebetegeknél (kreatinin >176 umol/l) az akut vesekárosodás gyakorisága ennél magasabb (12\%, illetve 9,6\%) volt [6]. Egy 1600 fót meghaladó, stabil, $60 \mathrm{ml} / \mathrm{min} / 1,73 \mathrm{~m}^{2}$ eGFR alatti vesefunkciójú betegeket vizsgáló koreai tanulmányban - hidrációs profilaxist alkalmazva - akut vesekárosodást a betegek 3,7\%-ában észleltek, ez a $30 \mathrm{ml} / \mathrm{min} / 1,73 \mathrm{~m}^{2}$ eGFR-értékú alcsoportban 10,8\%-ot ért el. Míg a kontrasztanyagos vizsgálatot követő hat hónapon belüli dialízisre kerülés magasabbnak bizonyult a vesekárosodást elszenvedókben, hat

1. táblázat | A kontrasztanyag-indukált vesekárosodás előfordulásának gyakorisága az eGFR függvényében $[11,16]$

\begin{tabular}{lll}
\hline eGFR-érték & $\begin{array}{l}\text { Intraarteriális } \\
\text { kontrasztanyag } \\
\text { alkalmazása }\end{array}$ & $\begin{array}{l}\text { Intravénás } \\
\text { kontrasztanyag } \\
\text { alkalmazása * }\end{array}$ \\
\hline$>90 \mathrm{ml} / \mathrm{min} / 1,73 \mathrm{~m}^{2}$ & & $\approx 0 \%$ \\
$60-89 \mathrm{ml} / \mathrm{min} / 1,73 \mathrm{~m}^{2}$ & $5,2 \%$ & $\approx 0 \%$ \\
$45-59 \mathrm{ml} / \mathrm{min} / 1,73 \mathrm{~m}^{2}$ & $8,0 \%$ & $\approx 0 \%$ \\
$30-44 \mathrm{ml} / \mathrm{min} / 1,73 \mathrm{~m}^{2}$ & $12,9 \%$ & $0-2 \%$ \\
$<30 \mathrm{ml} / \mathrm{min} / 1,73 \mathrm{~m}^{2}$ & $26,6 \%$ & $0-17 \%$ \\
\hline
\end{tabular}

*Az ACC Cath-PCI Regiszter adatai alapján [16]

**Az ACR és az NKF konszenzus-állásfoglalása alapján [11]

ACC $=$ Amerikai Kardiológiai Társaság; ACR = Amerikai Radiológusok Kollégiuma; eGFR = becsült glomerulusfiltrációs ráta; $\mathrm{NKF}=$ Nemzeti Vese Alapítvány (USA); PCI = percutan szívkoszorúér-beavatkozás hónapon túl már nem különbözött a két csoportban a dialízist igénylők aránya. A betegek halálozása nem növekedett a vesekárosodást elszenvedőkben, összehasonlítva azokkal, akikben nem lépett fel szövődmény a vizsgálat kapcsán [7]. További tanulmányokban $45 \mathrm{ml} /$ min/1,73 $\mathrm{m}^{2}$ feletti eGFR esetén a rizikó közel 0\%-nak bizonyult, 30-44 ml/min/1,73 $\mathrm{m}^{2}$ esetén 0-2\%, míg 30 $\mathrm{ml} / \mathrm{min} / 1,73 \mathrm{~m}^{2}$ eGFR alatt 0-17\% közötti CI-AKIgyakoriságot dokumentáltak $[9,11]$. Egy tajvani, egészségbiztosító adatbázisa alapján végzett vizsgálatban CKD miatt gondozás alatt álló, nagyszámú beteg adatait elemezték. Az eGFR-érték nem volt ismert a vizsgálók számára, de a betegek nem részesültek eritropoetinkezelésben, azaz a CKD nem volt jelentősen elörehaladott. Párosított valószínúségi mutatós összehasonlítással (propensity score) nem volt magasabb azok hosszú távú dialízisre kerülése, akik kontrasztanyagot kaptak a CT-vizsgálathoz, azokkal szemben, akiknél natívan készült a CT. Viszont lényegesen magasabbnak bizonyult a végstádiumú veseelégtelenség kialakulásának rizikója azoknál, akiknél egy év alatt több kontrasztanyagos CT is készült [17]. Ez utalhat az ismételt vizsgálatok rizikót növelő hatására, de arra is, hogy azok a betegek, akiknél sorozatban kellett CT-t készíteni, komorbiditásaikat tekintve súlyosabb állapotúak voltak. Ebben a vonatkozásban kiemelt figyelmet igényelnek az onkológiai betegek, akiknél a betegség alakulásának követésére nélkülözhetetlen ismételt CT-vizsgálatok végzése. A betegek érdekeit az indikáció gondos felállítása és a prevenciós intézkedések megtétele után minden indokolt vizsgálat kivitelezése képviseli.

Fontos megfigyelés, és ebben egyetértés mutatkozik a kutatók között, hogy az intravénás kontrasztanyag alkalmazását követő vesekárosodás vonatkozásában elsősorban a vesefunkció, azaz az eGFR csökkenése értékelendő rizikófaktorként; egyéb tényezők - diabetes mellitus, hypovolaemia, hypalbuminaemia, anaemia, magasabb életkor, nephrotoxicus gyógyszerek - növelhetik a kontrasztanyaggal társult vesekárosodás rizikóját, önmagukban azonban nem képezik a CI-AKI rizikótényezőjét $[1,12,15]$. Kiemelendő, hogy a GFR becslése pontatlan, ha a vesemúködés instabil, azaz akut veseelégtelenség áll fenn. Az állapot felismerését ilyenkor a szérumkreatinin és az óradiuresis szoros követése segíti.

A CI-AKI és a CA-AKI rizikójának becslésére azonban indokoltnak látszik a GFR mellett a proteinuria mértékének figyelembevétele is, mivel a kombinált eGFR-proteinuria táblázat nemcsak az idült vesebetegség súlyosságát, hanem az erre rakódó akut vesekárosodás kockázatát is pontosabban jelzi. A kóros mértékü albuminuria a normális albuminuriához képest 2-3-szorosára emeli minden GFR-stádiumban a rárakódó akut vesekárosodás kockázatát [18]. A proteinuria a CI-AKI-re koncentráló tanulmányokban is független rizikótényezőnek bizonyult stroke-betegekben [19], valamint koronarográfián átesettekben is $[20,21]$. A proteinuria jelenléte magyarázhatja a korábbi vizsgálatokban gyakran észlelt CI-AKI 
nagyobb gyakoriságát diabetes mellitusban és myeloma multiplexben. A kontrasztanyagos vizsgálatok előtt elvégzett korrekt fehérjevizelés-vizsgálat (vizelet albumin/ kreatinin hányados: uACR vagy vizelet fehérje/kreatinin hányados: uPCR) a vizsgálattal kapcsolatos rizikóbecslésen túl az idült vesebetegek felismerését és a betegek prognózisának pontosítását is nagyban segítené. Jelentős, napi 0,5 g fehérjevizelést jelez, ha az uACR >30 $\mathrm{mg} / \mathrm{mmol}$ vagy az uPCR $>50 \mathrm{mg} / \mathrm{mmol}$, de már a mérsékelt fehérjevizelés (uACR $>3 \mathrm{mg} / \mathrm{mmol}$ vagy uPCR $>15 \mathrm{mg} / \mathrm{mmol}$ ) is indokolhatja a preventív intézkedések megtételét.

A fentiek alapján a szakértők szerint az intravénás kontrasztanyag alkalmazása még beszúkült vesefunkció esetén is viszonylag alacsony rizikóval jár, ezért nem ellenjavallt még CKD IV-V. stádiumú veseelégtelenség esetén sem, ha nélkülözhetetlen fontosságú a vizsgálat által elérhető diagnosztikai eredmény érdekében [11, 22]. Hasonló megfontolások érvényesek a még maradék vesefunkcióval bíró dializáltaknál is. A kontrasztanyagos vizsgálat indikációját tehát annak rizikója és a várható eredmények mérlegelése alapján kell felállítani [11]. A vesetranszplantáltak és a szoliter vesével élók esetében az egy funkcionáló vese állapota nem képez eltérő megfontolást, a rizikót náluk is az eGFR-érték alapján kell meghatározni [12]. Kontrasztanyag alkalmazását követő dialíziskezeléssel nem befolyásolható az esetleges vesekárosodás, alkalmazása ilyen megfontolásból indokolatlan [13]. Végstádiumú veseelégtelen betegekben a vizsgálatot követően akkor szükséges soron kívüli dialízist végezni, ha a kontrasztanyag beadása annak magas ozmolalitása miatt, illetve a preventív rehidrálás hiperhidráció, tüdővizenyő veszélyével jár, egyéb céllal esetükben sem indikált sürgős hemodialízis-kezelés. Peritonealis dialíziskezelésben részesülőknél a kontrasztanyag alkalmazása miatti hemodialízis elvégzése indokolatlan [8]. A myeloma multiplex önmagában nem képezi a kontrasztanyag alkalmazásának ellenjavallatát, csak a fenti rizikófaktorok jelenléte esetén [13].

\section{A kontrasztanyag által okozott akut vesekárosodás gyakorisága a kontrasztanyag intraarteriális alkalmazásakor}

Az elmúlt években számos megfigyeléses és randomizált tanulmány jelent meg koronarográfiás és coronariaintervenciós beavatkozások kapcsán dokumentált CI-AKIesetekról $[3,16,23]$. A teljes betegpopuláció vonatkozásában a szövődmény kialakulása 3,3-10,2\%-osra becsülhető, de alapvetően meghatározó az egyéb rizikófaktorok, elsősorban a vesefunkció: a kiindulási szérum kreatinin/eGFR érték (1. táblázat), illetve akut veseelégtelenség esetén az eGFR helyett az óradiuresis. A CI-AKI előfordulásának gyakoriságát jól reprezentálja a Cath-PCI Regiszter 2009 és 2011 között létrehozott adatbázisa: ebben több mint 900000 vizsgálatot követően határozták meg a beavatkozás kapcsán kialakult vesefunkció-romlás és dialízist igénylő veseelégtelenség előfordulását, amely a teljes betegpopulációban 7,1\%-osnak bizonyult; dialízist a betegek $0,3 \%$-a igényelt. 30 $\mathrm{ml} / \mathrm{min} / 1,73 \mathrm{~m}^{2}$ eGFR alatt a betegek 26,6\%-ában észleltek vesefunkció-romlást, dialízist 4,3\%-uknál kellett bevezetni [16]. A CI-AKI kialakulását a rizikótényezők, elsősorban a CKD és a cardiovascularis instabilitás halmozott jelenléte növelte a többszörösére. Ezzel szemben japán kutatók $30 \mathrm{ml} / \mathrm{min} / 1,73 \mathrm{~m}^{2}$ alatti eGFR-értékkel bíró betegekben csak 9,7\%-ban észleltek CI-AKI-t. Amikor összehasonlították azokat, akiknél kialakult a szövődmény, azokkal, akiknek nem romlott a vesemúködésük, azt találták, hogy a két csoportban nem különbözött az alap-eGFR-érték, de a szövődményes betegek körében gyakoribb volt a cardiovascularis instabilitás, több kontrasztanyagot kaptak, és alacsonyabb mennyiségü preventív folyadékbevitelben részesültek [23]. A szerzők megjegyzik, hogy coronariaintervenciós centrumukban a kontrasztanyagot kis mennyiségben alkalmazták $(72 \pm 57 \mathrm{ml})$, és a betegek nagyobb része intravénás infúziós prevencióban részesült.

Az adatok egyértelmúen bizonyítják, hogy az utóbbi években a veseszövődmény gyakorisága mérséklődött, ami részben a preventív stratégiák alkalmazásának köszönhető, részben pedig a katéterezési technika fejlődésének, mint például az arteria radialis behatolásból végzett katéterezés: ezáltal kevesebbszer következik be vérzéses szövődmény vagy koleszterinkristály-embolisatio. A rizikó mértékét jelentősen befolyásolja a beteg állapota is: az akut STEMI kapcsán végzett PCI eseteiben a rizikó magasabb, az incidenciát 10,5-18,3\%-ban határozták meg, ami reprezentálja az esendőbb betegek magasabb szövődményrátáját, és magyarázza ezzel összefüggésben a magasabb mortalitást is [14].

Egyéb artériás intervenció esetén észlelt CI-AKI vonatkozásában kevesebb epidemiológiai adat áll rendelkezésre. Perifériás angiográfia, arteria carotis/aorta sztent implantációja vagy TAVI (transzkatéteres aortabillentyüimplantáció) végzésekor magas rizikójú betegekben relatíve magas számban tapasztaltak akut vesekárosodást (22-34\%), azonban ezen betegek többszörös komorbiditása esendővé teszi őket renalis szövődmény kialakulására, amiért valószínúleg nemcsak a kontrasztanyag, hanem a társbetegségek is felelőssé tehetők [14].

\section{Rizikófaktorok és prevenciós lehetőségek}

A fentiek alapján az akut vesekárosodás kialakulásának legfontosabb rizikótényezője a beteg vesefunkciója, melyet az ESUR irányelve intraarteriális kontrasztanyag alkalmazásakor - egyéb rizikótényezőkkel rendelkezőkben, intenzív osztályon kezeltekben - $45 \mathrm{ml} / \mathrm{min} / 1,73 \mathrm{~m}^{2}$ eGFR-értékben határoz meg, intravénás kontrasztanyag alkalmazásakor pedig rizikócsoportnak a $30 \mathrm{ml} / \mathrm{min} /$ 1,73 $\mathrm{m}^{2}$ alatti eGFR-értékú betegeket tartja $[8,12,13]$. 
Rizikótényező intraarteriális kontrasztanyagos vizsgálat esetén az ST-elevációval járó myocardialis infarktus, a cardiogen shock, továbbá nagy valószínúséggel növeli a kockázatot a diabetes mellitus, az anaemia, a szívelégtelenség, az alacsony ejekciós frakció és az idős, 70-75 év feletti életkor [2]. A rizikóban alapvető szerepet játszik az aktuális klinikai állapot, a vesemúködés instabilitása, a beteg hemodinamikai instabilitása, azaz a hypovolaemás állapot, a shock, a sürgősségi beavatkozás ténye és a vesefunkciót egyidejúleg károsító egyéb tényezők jelenléte, mint a nephrotoxicus gyógyszerek, továbbá a kontrasztanyag alkalmazásának paraméterei, annak mennyisége és típusa, ismételt vizsgálat 48-72 órán belül, az angiográfiás beavatkozás helye, intraaorticus eszköz jelenléte [13]. Egy 12 közleményt magában foglaló, több mint 6000, STEMI miatt PCI-ben részesülő beteg adatait összesítő metaanalízisben, ahol a betegek 13,3\%-a szenvedett el CI-AKI-t, rizikótényezőnek véleményezték a beszúkült vesefunkciót, a diabetes mellitust, az életkort, a hypertoniát és a rossz cardialis állapotot, mely magában foglalta az alacsony ejekciós frakciót, az anamnesztikus myocardialis infarktust, a bal descendens anterior koszorúér érintettségét és a Killip $\geq 2$. osztályba tartozást [24]. Fontos azonban kiemelni, hogy számos szakértő véleménye szerint az időskor, a diabetes, az anaemia és a szívelégtelenség nem a kontrasztanyag-indukált vesekárosodás, hanem a kontrasztanyag-asszociált vesekárosodás etiológiai tényezői $[11,15]$.

A legjelentősebb prevenciós stratégia a megfelelő hidráltság biztosítása, amit intravénás folyadékbevitellel kell elérni $[25,26]$. A klinikai tanulmányok alapján, intravénás kontrasztanyag alkalmazásakor, stabil állapot esetén csak a $30 \mathrm{ml} / \mathrm{min} / 1,73 \mathrm{~m}^{2}$ alatti eGFR-értékkel bíró betegeknél szükséges preventív intravénás hidrálás. A 30-45 ml/min/1,73 m² eGFR-értékú betegekben akkor szükséges prevenció, ha intraarteriális kontrasztanyag-adagolást terveznek, ha a vesefunkció instabil, és / vagy a beteg további rizikótényezővel bír [11, 12]. Ezek közül a korábban tárgyalt szempontok miatt kiemelendőnek tartjuk a proteinuriát. Jelenléte esetén intravénás kontrasztanyag adásakor már a 30-44 ml/min/1,73 m² közötti, intraarteriális adás esetén a $45-59 \mathrm{ml} / \mathrm{min} /$ 1,73 $\mathrm{m}^{2}$ közötti eGFR esetén is javasoljuk a hidrálás alkalmazását (1. ábra). Preventív intézkedés ennél enyhébb vesebetegség vagy normális vesefunkció esetén - amennyiben a beteg volumenstatusa rendezett - szükségtelennek látszik, amit többek között a nemrégiben publikált AMACING-vizsgálat is alátámasztott [27].

Az intavénás hidrálás többféle séma szerint alkalmazható. Randomizált klinikai vizsgálatok bizonyítják a hatékony prevenciót $1 \mathrm{ml} / \mathrm{kg} / \mathrm{h}$ intravénás fiziológiás sóinfúzióval, 12 órával a beavatkozás előtt indítva és azt követően az ejekciós frakciótól függően $0,5-1 \mathrm{ml} / \mathrm{kg} / \mathrm{h}$ mennyiségben, 24 órán keresztül folytatva. Akut szituációkban az elhúzódó időtartamú hidrálás nem kivitelezhető, ilyenkor $3 \mathrm{ml} / \mathrm{kg} / \mathrm{h}$ Salsollal történő infundálás javasolt, lehetőleg 4 órával a beavatkozás előtt megkezd- ve és azt követően csökkentett dózisban még 4 órán keresztül folytatva [14]. Más protokollokban a kontrasztanyagos vizsgálatot 1 órával megelőzően $3 \mathrm{ml} / \mathrm{kg} / \mathrm{h}$, majd utána 3-12 órán át $1 \mathrm{ml} / \mathrm{kg} / \mathrm{h}$ mennyiségben adagolták a fiziológiás sóinfúziót. Amennyiben a vizsgálat előtt rövid idő áll rendelkezésre, Salsol helyett adható Alkaligen (1,4\%-os nátrium-bikarbonát) infúziója is, $3 \mathrm{ml} / \mathrm{kg}$ a kontrasztanyag alkalmazása előtt és után 1-1 órával $[2,8,11]$. Sürgős beavatkozás esetén, amennyiben előhidrálásra nincs idő, rizikócsökkentéssel jár az azt követő intravénás folyadékbevitel is. Az infúzió mennyiségének megtervezésekor mérlegelni kell az akut szívelégtelenség, a hiperhidráció kialakulásának veszélyét, ezekben az esetekben a folyadék mennyisége csökkentendő. Az intravénás hidrálás hatékonysága egyértelmüen meghaladja a per os folyadékbevitel eredményességét, ez utóbbi prevencióként nem elegendő [13]. Azokban a tanulmányokban, melyekben a nátrium-bikarbonát infúziójával végzett prevenciót hasonlították a fiziológiás sóinfúzió hatékonyságához, hasonló eredményeket kaptak [8, 15]. Közülük az egyik legközismertebb a PRESERVEvizsgálat, mely azt igazolta, hogy olyan betegekben, akiknek az eGFR-értéke 15-60 ml/min/1,73 m² közötti, az izotóniás nátrium-bikarbonát infúziója nem kevésbé eredményes, de nem is hatékonyabb a Salsol infúziónál [28].

Napjainkban is számos hatóanyaggal végeznek kutatásokat a CI-AKI-prevenció irányában. Ezek egyik csoportját képezik a sztatinkészítmények, azok pleiotrop, antiinflammatoricus, antioxidáns, apoptózisgátló hatása alapján - a CI-AKI azonban vonatkozásában sokan megkérdőjelezik e szerek hatékonyságát [14, 29-31]. Az ESUR nem találta előnyösnek és nem javasolja a prevenciós sztatinadagolást [8]. A korábbi években a prevencióban pozitív eredménnyel kecsegtető $\mathrm{N}$-acetil-cisztein vonatkozásában számos klinikai vizsgálatban igazolták annak hatástalanságát, ez alapján alkalmazása indokolatlan [28]. Szintén nem bizonyult hatékonynak számos más szer prevencióként (például teofillin, C-vitamin, trimetazidin, alprosztadil, iloproszt).

Fontos a renalis perfusiót, vasodilatatiót gátló nonszteroidok mellőzése. Ezeket lehetőség szerint 24 órával a kontrasztanyaggal végzett vizsgálatot megelőzően el kell hagyni, azt követően pedig a beteg a szert csak akkor kaphatja vissza, ha a vesefunkció nem romlott, illetve stabilizálódott. Célszerű $30 \mathrm{ml} / \mathrm{min} / 1,73 \mathrm{~m}^{2}$ alatti eGFR-értékű betegben az egyéb vesekárosító szerek (aminoglikozidok, amfotericin, ciszplatin, zolendronát, metotrexát, illetve a diuretikum) szüneteltetése 24-48 órával a vizsgálatot megelőzően és 48 órával azt követően $[11,14]$. Az ACE-gátlók, ARB-k alkalmazásának átmeneti felfüggesztésével kapcsolatos eredmények vitatottak, ebben a kérdésben jelenleg még nincs konszenzus $[8,32]$.

A CI-AKI kialakulásának a GFR-en kívüli másik meghatározó rizikótényezője az alkalmazott kontrasztanyag mennyisége. Bár az intravénás kontrasztanyagos CT- 
vizsgálatokat előre meghatározott kontrasztanyag-menynyiséggel végzik, amely kevéssé módosítható, ezekhez a vizsgálatokhoz nem kell nagy dózist alkalmazni, ezért rizikónövelő hatásuk mérsékelt. Intraarteriális adagolás esetén azonban a dózis függhet a beavatkozás technikájától, korábbi bypass jelenlététől, a szükséges intervenciók számától is [16]. Egyes tanulmányok szerint a vese által „tolerált” mennyiség arányos a szérumkreatinin értékével. A vizsgálatot végző szerzők 2,7-3,7 közötti kontrasztanyag-mennyiség $(\mathrm{ml}) / \mathrm{eGFR}$ arányt véleményeznek biztonságosnak [12,33]. Ennek megfelelően az Európai Kardiológiai Társaság $45 \mathrm{ml} / \mathrm{min}$ alatti eGFR esetén javasolja a kontrasztanyag mennyiségének lehetőség szerinti korlátozását [31]. Leginkább a többszörös intervenciók során alkalmazott nagy dózisok elkerülése esetén mérlegelendő a beavatkozás két lépcsőben való elvégzése. Fontos továbbá, hogy ismételt kontrasztanyagos vizsgálat minél később, de mindenképpen a vesefunkció stabilizálódását követően készüljön. A vizsgálat ismétlésénék időkorlátját az ESUR irányelve 48 órában határozza meg. Amennyiben az eGFR $30 \mathrm{ml} / \mathrm{min} / 1,73$ $\mathrm{m}^{2}$ feletti, és MR-vizsgálatra is szükség van, a beteg kaphat gadolíniumot a radiojód kontrasztanyagos vizsgálat után 4 órával. Ha az eGFR $30 \mathrm{ml} / \mathrm{min} / 1,73 \mathrm{~m}^{2}$ alatti, a két képalkotó elvégzése között teljen el 7 nap [13].

A kontrasztanyagos vizsgálatok „hőskorában” igen magas ozmolalitású anyagokat alkalmaztak, melyek vesekárosodást okozó mellékhatása jelentősnek bizonyult. Napjainkban ezeket a készítményeket már kivonták a forgalomból. A leggyakrabban használatos kontrasztanyagok az úgynevezett „alacsony ozmolalitásúak”: ezek ozmolalitása 500-900 mOsm/kg közötti, ami még mindig jelentősen meghaladja a szérumét (például iohexol, iomeprol, iopamidol, iopromid, ioverzol, ioxilan). Ezzel szemben az izoozmoláris készítmény (iodixanol) a szérumozmolalitással megegyező, $290 \mathrm{mOsm} / \mathrm{kg}$ töménységü, ugyanakkor a készítmény viszkozitása magasabb, mint az alacsony ozmolalitásúaké [16]. Az ozmolalitás alapján két típusba sorolható készítményeket számos vizsgálatban hasonlították össze a CI-AKI vonatkozásában. Bár több vizsgálat alacsonyabb rizikóval járónak értékelte az izoozmoláris iodixanolt, más eredmények ezt az előnyös hatást megkérdőjelezték [34-36]. Ez alapján, illetve mivel napjainkban az izoozmoláris kontrasztanyag rutinszerú alkalmazását annak magasabb ára korlátozza, nemzetközi konszenzus szerint az alacsony ozmolalitásúak rutinszerúen alkalmazhatók, az általuk okozott rizikó a betegek összességében nem magasabb az izoozmolárisokéhoz képest [11]. Magas rizikójú beteg ellátásakor, különösen intraarteriálisan alkalmazva, az izoozmoláris kontrasztanyag előnyösebb volta felvethető, és a klinikai adatokat figyelembe véve annak előnyben részesítése mérlegelendő [16].

Amennyiben a beteg rizikója magas CI-AKI kialakulására, javasolt alternatív képalkotó módszer lehetősé- gének megfontolása. A kontrasztanyag alkalmazását követően 48 órával készüljön laborvizsgálat, CI-AKI bekövetkezte esetén a vesefunkciót legalább 30 napig obszerválni kell [13].

\section{Kontrasztanyag alkalmazása metformint szedő betegekben}

A metformin önmagában nem nephrotoxicus. Veszélye, hogy amennyiben akut veseelégtelenség alakul ki, a metformin kumulálódik, és ezáltal súlyos laktátacidózist okozhat. Tekintve, hogy $60 \mathrm{ml} / \mathrm{min} / 1,73 \mathrm{~m}^{2}$ eGFR-érték feletti vesefunkció esetén - egyéb CI-AKI-rizikófaktor hiányában - az akut vesekárosodás rizikója elhanyagolható, ezekben a betegekben a metformin elhagyása szükségtelen $[2,13]$. A rizikóval bíró betegekben, $45 \mathrm{ml} / \mathrm{min} / 1,73 \mathrm{~m}^{2}$ eGFR alatti vesemúködésnél, az ESUR és az Európai Kardiológiai Társaság irányelvei elegendőnek tartják a metformin elhagyását a vizsgálat időpontjában; a szer szedésének folytatása akkor engedélyezhető, ha a vesefunkció 48 óra múlva nem romlott $[8,13,31]$. Ezzel szemben az ACR irányelvében - a fentiekkel megegyező véleményen túl - említésre kerül az FDA javaslata is, mely szerint a metformin szedését célszerü felfüggeszteni $30-59 \mathrm{ml} / \mathrm{min} / 1,73 \mathrm{~m}^{2}$ eGFR esetén, illetve a rizikót és a szer szedésének szüneteltetését ilyen vesemúködésnél egyénileg kell meghatározni [11]. Mivel a szer $30 \mathrm{ml} / \mathrm{min} / 1,73 \mathrm{~m}^{2}$ eGFR-érték alatt, továbbá akut veseelégtelenségben amúgy is kontraindikált, a CKD IV. stádiumú és az akut vesebetegek esetében a metformint mindenképpen mellőzni kell.

\section{A napjaink kutatásainak tárgyát képező további prevenciós lehetőségek}

Automata kontrasztanyag-injektáló eszköz alkalmazásával alacsonyabb kontrasztmennyiség beadását lehet biztosítani anélkül, hogy az limitálná a vizsgálat eredményességét. Egy másik lehetőség a beadott kontrasztanyag reaspirációja a sinus coronariusból, mely ígéretesnek látszó, de további vizsgálatokat igénylő technika [14]. RenalGuard-nak nevezték el azt a prevencióban alkalmazott, hidrációmennyiséget optimalizáló eszközt, amely az ürített vizeletmennyiség függvényében adagolja a betegnek az intravénás infúziót, célul tûzve a $450 \mathrm{ml} / \mathrm{h}$ feletti óradiuresis elérését a beavatkozás során. A RenalGuard alkalmazásával végzett hidrálás egyértelmúen hatékonyabbnak bizonyult a „klasszikus”, előre meghatározott mennyiségű folyadékbevitellel szemben. Szintén előnyös, ha a preventív folyadékbevitel volumenének meghatározása hemodinamikai méréseken alapul, akár a bal kamrai végdiastolés nyomás, akár a centrális nyomás vagy bioimpedancia-analízis alapján kerül meghatározásra [26]. 


\section{Következtetés}

A napjainkban rendelkezésre álló adatok alapján CI-AKI ritkábban alakul ki, mint azt a korábbi években gondoltuk. Elsősorban koszorúérbetegekben, a koronarográfia kapcsán végzett kontrasztanyagos vizsgálattal, beavatkozással egyidejúleg fennállhat hemodinamikai-cardiovascularis instabilitás is, ennek következtében akutan romolhat a vesefunkció, azaz CA-AKI következhet be, melyben azonban a kontrasztanyag nem játszik oki szerepet. CI-AKI kialakulása gyakoribb intraarteriálisan, mint intravénásan alkalmazott kontrasztanyag esetén. A legfontosabb rizikótényező a rossz vesefunkció, ez alapján intraarteriális vizsgálatnál a $45 \mathrm{ml} / \mathrm{min} / 1,73 \mathrm{~m}^{2}$ alatti, intravénás vizsgálatnál a $30 \mathrm{ml} / \mathrm{min} / 1,73 \mathrm{~m}^{2}$ alatti eGFR-értékkel rendelkező, továbbá az instabil vesefunkciójú betegek számára javasolt prevenciós hidrálás, fiziológiás, vagyis $0,9 \%$-os nátrium-klorid vagy $1,4 \%$-os nátrium-bikarbonát infúziójával. A kontrasztanyagos vizsgálat klinikai indikáció fennállásakor a magas rizikóval rendelkező betegeknél is elvégzendő. A kontrasztanyag beadását követően 48 órával ellenőrizni kell a vesefunkciót: amennyiben az romlott, a beteg további megfigyelést igényel. Magas rizikójú betegekben, intraarteriális vizsgálatoknál izoozmoláris kontrasztanyag preferálandó; célszerű a kontrasztanyag mennyiségének lehetőség szerinti redukálása, a kontrasztanyag ml-ben meghatározott volumenének és az eGFR-nek a hányadosa ne haladja meg a 3-at. Javasolt a kontrasztanyagos vizsgálatok rövid időn belüli ismétlésének elkerülése. A metformint $60 \mathrm{ml} / \mathrm{min} / 1,73 \mathrm{~m}^{2}$ eGFR felett nem szükséges szüneteltetni. Alacsonyabb eGFR-nél célszerü 1 nappal a vizsgálat előtt kihagyni, de sürgősségi indikáció esetén a metforminszedés miatt nem kell halasztani a vizsgálatot: a metformint a vizsgálat időpontjában el kell hagyni, az eGFR-t 48 óra múlva ellenórizni kell, és az antidiabetikum adagolását csak a vesemúködés stabilitása esetén szabad ismét bevezetni.

Anyagi támogatás: A közlemény megírása nem részesült anyagi támogatásban.

Szerzői munkamegosztás: A szerzők közösen készítették el a kéziratot. A cikk végleges változatát mindkét szerző elolvasta és jóváhagyta.

Érdekeltségek: A szerzőknek nincsenek érdekeltségeik.

\section{Irodalom}

[1] Luk L, Steinman J, Newhouse JH. Intravenous contrast-induced nephropathy - the rise and fall of a threatening idea. Adv Chronic Kidney Dis. 2017; 24: 169-175.

[2] Morcos R, Kucharik M, Bansal P, et al. Contrast-induced acute kidney injury: review and practical update. Clin Med Insights Cardiol. 2019; 13: 1179546819878680.

[3] Abe M, Morimoto T, Nakagawa Y, et al. Impact of transient or persistent contrast-induced nephropathy on long-term mortality after elective percutaneous coronary intervention. Am J Cardiol. 2017; 120: 2146-2153.

[4] Sedhai YR, Golamari R, Timalsina S, et al. Contrast-induced nephropathy after cardiac catheterization: culprits, consequences and predictors. Am J Med Sci. 2017; 354: 462-466.

[5] Do C. Intravenous contrast: friend or foe? A review on contrastinduced nephropathy. Adv Chronic Kidney Dis. 2017; 24: 147149.

[6] McDonald RJ, McDonald JS, Carter RE, et al. Intravenous cont rast material exposure is not an independent risk factor for dialysis or mortality. Radiology 2014; 273: 714-725.

[7] Park S, Kim MH, Kang E, et al. Contrast-induced nephropathy after computed tomography in stable CKD patients with proper prophylaxis: 8-year experience of outpatient prophylaxis program. Medicine (Baltimore) 2016; 95: e3560.

[8] van der Molen AJ, Reimer P, Dekkers IA, et al. Post-contrast acute kidney injury. Part 2: risk stratification, role of hydration and other prophylactic measures, patients taking metformin and chronic dialysis patients: recommendations for updated ESUR Contrast Medium Safety Committee guidelines. Eur Radiol. 2018; 28: 2856-2869.

[9] McDonald RJ, McDonald JS, Newhouse JH, et al. Controversies in contrast material-induced acute kidney injury: closing in on the truth? Radiology 2015; 277: 627-632.

[10] Haris Á, Nagy J, Mátyus J. Recommendations for prevention of contrast-induced nephropathy. Clinical guideline. [Állásfoglalás a kontrasztanyagok vesekárosító hatásának megelőzésére. Szakmai irányelv.] Hyperton Nephrol. 2012; 16: 163-166. [Hungarian]

[11] Davenport MS, Perazella MA, Yee J, et al. Use of intravenous iodinated contrast media in patients with kidney disease: consensus statements from the American College of Radiology and the National Kidney Foundation. Radiology 2020; 294: 660-668.

[12] van der Molen AJ, Reimer P, Dekkers IA, et al. Post-contrast acute kidney injury. Part 1: definition, clinical features, incidence, role of contrast medium and risk factors: Recommendations for updated ESUR Contrast Medium Safety Committee guidelines. Eur Radiol. 2018; 28: 2845-2855.

[13] European Society of Urogenital Radiology. ESUR guidelines on contrast agents. 10.0. Section B. Renal adverse reactions (postcontrast acute kidney injury, PC-AKI). Contrast Media Safety Committee, March 2018; pp. 17-25.

[14] Ronco F, Tarantini G, McCullough PA. Contrast induced acute kidney injury in interventional cardiology: an update and key guidance for clinicians. Rev Cardiovasc Med. 2020; 21: 9-23.

[15] Mehran R, Dangas GD, Weisbord SD. Contrast-associated acute kidney injury. N Engl J Med. 2019; 380: 2146-2155.

[16] McCullough PA, Choi JP, Feghali GA, et al. Contrast-induced acute kidney injury. J Am Coll Cardiol. 2016; 68: 1465-1473.

[17] Hsieh MS, Chiu CS, How CK, et al. Contrast medium exposure during computed tomography and risk of development of endstage renal disease in patients with chronic kidney disease: a nationwide population-based, propensity score-matched, longitudinal follow-up study. Medicine (Baltimore) 2016; 95: e3388.

[18] Levey AS, de Jong PE, Coresh J, et al. The definition, classification, and prognosis of chronic kidney disease: a KDIGO Controversies Conference report. Kidney Int. 2011; 80: 17-28. [Erratum: Kidney Int. 2011; 80: 1000.]

[19] Tao Y, Dong W, Li Z, et al. Proteinuria as an independent risk factor for contrast-induced acute kidney injury and mortality in patients with stroke undergoing cerebral angiography. J Neurointerv Surg. 2017; 9: 445-448.

[20] Wang C, Ma S, Deng B, et al. The predictive value of the product of contrast medium volume and urinary albumin/creatinine ratio in contrast-induced acute kidney injury. Ren Fail. 2017; 39: $555-560$.

[21] Saito Y, Watanabe M, Aonuma K, et al. CINC-J study investigators. Proteinuria and reduced estimated glomerular filtration rate 
are independent risk factors for contrast-induced nephropathy after cardiac catheterization. Circ J. 2015; 79: 1624-1630.

[22] Rose TA Jr, Choi JW. Intravenous imaging contrast media complications: the basics that every clinician needs to know. Am J Med. 2015; 128: 943-949.

[23] Negishi Y, Tanaka A, Ishii H, et al. Contrast-induced nephropathy and long-term clinical outcomes following percutaneous coronary intervention in patients with advanced renal dysfunction (estimated glomerular filtration rate $<30 \mathrm{ml} / \mathrm{min} / 1.73 \mathrm{~m}^{2}$ ). Am J Cardiol. 2019; 123: 361-367.

[24] He H, Chen XR, Chen YQ, et al. Prevalence and predictors of contrast-induced nephropathy $(\mathrm{CIN})$ in patients with ST-segment elevation myocardial infarction (STEMI) undergoing percutaneous coronary intervention (PCI): a meta-analysis. J Interv Cardiol. 2019; 2019: 2750173.

[25] Liu Y, Hong D, Wang AY, et al. Effects of intravenous hydration on risk of contrast induced nephropathy and in-hospital mortality in STEMI patients undergoing primary percutaneous coronary intervention: a systematic review and meta-analysis of randomized controlled trials. BMC Cardiovasc Disord. 2019; 19: 87.

[26] Cai Q, Jing R, Zhang W, et al. Hydration strategies for preventing contrast-induced acute kidney injury: a systematic review and bayesian network meta-analysis. J Interv Cardiol. 2020; 2020: 7292675.

[27] Nijssen EC, Rennenberg RJ, Nelemans PJ, et al. Prophylactic hydration to protect renal function from intravascular iodinated contrast material in patients at high risk of contrast-induced nephropathy (AMACING): a prospective, randomised, phase 3, controlled, open-label, non-inferiority trial. Lancet 2017; 389: 1312-1322.

[28] Weisbord SD, Gallagher M, Jneid H, et al., PRESERVE Trial Group. Outcomes after angiography with sodium bicarbonate and acetylcysteine. Lancet 2017; 389: 1312-1322.

[29] Cho A, Lee YK, Sohn SY. Beneficial effect of statin on preventing contrast-induced acute kidney injury in patients with renal insufficiency: a meta-analysis. Medicine (Baltimore) 2020; 99: e19473.
[30] Liang M, Yang S, Fu N. Efficacy of short-term moderate or highdose rosuvastatin in preventing contrast-induced nephropathy: a meta-analysis of 15 randomized controlled trials. Medicine (Baltimore) 2017; 96: e7384.

[31] Neumann FJ, Sousa-Uva M, Ahlsson A, et al. ESC Scientific Document Group. 2018 ESC/EACTS guidelines on myocardial revascularization. Eur Heart J. 2019; 40: 87-165. [Erratum: Eur Heart J. 2019; 40: 3096.]

[32] Bainey KR, Rahim S, Etherington K, et al., CAPTAIN Investigators. Effects of withdrawing vs continuing renin-angiotensin blockers on incidence of acute kidney injury in patients with renal insufficiency undergoing cardiac catheterization: results from the angiotensin converting enzyme inhibitor/angiotensin receptor blocker and contrast induced nephropathy in patients receiving cardiac catheterization (CAPTAIN) trial. Am Heart J. 2015; 170: 110-116.

[33] Laskey WK, Jenkins C, Selzer F, et al., NHLBI Dynamic Registry Investigators. Volume-to-creatinine clearance ratio: a pharmacokinetically based risk factor for prediction of early creatinine increase after percutaneous coronary intervention. J Am Coll Cardiol. 2007; 50: 584-590.

[34] Zhang J, Jiang $Y$, Rui Q, et al. Iodixanol versus iopromide in patients with renal insufficiency undergoing coronary angiography with or without PCI. Medicine (Baltimore) 2018; 97: e0617.

[35] Zhao F, Lei R, Yang SK, et al. Comparative effect of iso-osmolar versus low-osmolar contrast media on the incidence of contrastinduced acute kidney injury in diabetic patients: a systematic review and meta-analysis. Cancer Imaging 2019; 19: 38.

[36] Aspelin P, Aubry P, Fransson SG, et al. Nephrotoxic effects in high-risk patients undergoing angiography. N Engl J Med. 2003; 348: $491-499$

(Haris Ágnes dr., Budapest, Péterfy S. u. 8-20., 1076 e-mail: agnesharis@hotmail.com)

\section{"Tempora mutantur et nos mutamur in illis." (Változnak az idők, és velük mi is változunk.)}

A cikk a Creative Commons Attribution 4.0 International License (https://creativecommons.org/licenses/by/4.0/) feltételei szerint publikált Open Access közlemény, melynek szellemében a cikk bármilyen médiumban szabadon felhasználható, megosztható és újraközölhetö, feltéve, hogy az eredeti szerző és a közlés helye, illetve a CC License linkje és az esetlegesen végrehajtott módositások feltüntetésre kerülnek. (SID_1) 